\title{
Evaluation and Training Scheme for the Management Post Competence for "ZhouHeiya"
}

\author{
Gao Nanxin \\ School of Management \\ Wuhan University of Science and Technology \\ Wuhan, China
}

\author{
LI Yongzhou \\ School of Management \\ Wuhan University of Science and Technology \\ Wuhan, China
}

\begin{abstract}
The enterprise management training based on post competence is a necessary choice for enterprise to keep and increase core competitiveness in the "Talent Time". Taking ZhouHeiya Food Corporation for example, this article makes comprehensive analysis based on the development strategy and post competence of the corporation. By reference to theoretical literature and benchmarking enterprises, it establishes the model for the competence of the management posts in ZhouHeiya. It pointedly designs training contents and ways and established enterprise management training course system; it chooses corresponding training contents and ways based on the evaluation result about the management post competence to increase the management post competence and support the sustainable development for the corporation. It further expects to provide some reference for other middle and small-sized enterprises in rapid growth.
\end{abstract}

Keywords-ZhouHeiya; core staff post competence; training scheme; evaluation

\section{INTRODUCTION}

Staff training is an important pivot for enterprise development, the basic approach for human resource development and also an important means for promoting enterprise management reform and increasing management level. Especially in recent years, due to the continuous influence of worldwide economic crisis, innovation has become an important means for enterprises to pursue new competitive advantages. The evaluation on staff post competence quality, core capacity construction and continuous training have further become necessary choice for enterprises to get away from crisis. Different from traditional schemes based on training demand analysis, the training scheme based on post competence is a personalized training way through deep analysis on posts in the pursuit of post competence model by comparison between the staff individual quality and post competence to pointedly design training contents and ways, aiming to fully increase the staff post competence to realize person-post matching, staff potential development and staff incentive. In the training system based on post competence, trainers will turn from "knowledge spreader" to "knowledge creator". The training way will turn from "inheritance type" to "innovation type". The training content will turn from "vacancy fill" to "potential extraction". The training goal will turn from "focus on organizational development" to "focus on organizational development and individual development”. The training based on post competence can fully reflect the strategic status of training, strengthen the enterprise cultural idea, establish learning organization and increase staff work quality and performance. Taking ZhouHeiya Food Corporation for example, this article aims to design post-competence-based enterprise management training scheme based on the corporate development strategy and management post competence requirement, expecting to deepen the theoretical discussion and practical application research about management post competence training.

\section{COMPANY PROFILE AND CASE BACKGROUND}

"ZhouHeiya" is mainly specified in the production, marketing and retailing of "ZhouHeiya" series of leisure stewed dishes, including duck necks, duck wings, duck clavicles, duck tones and duck flippers. Meanwhile, it also provides stewed red meat, vegetables and other fowl products. For 20 years, ZhouHeiya has developed from a small private workshop to the large-scale private enterprise now. It succeeded in public listing in Hong Kong Exchange on November 11th of 2016. The corporation has established friendly cooperative relationships with upstream enterprises, realizing central kitchen operation mode of "Corporation+ Farmers+ Basement" so that the product quality has got steady and strengthened and the brand has got greatly increased. Especially in recent years, the corporation took the lead in introducing ERP management system and established and improved O2O's operation system and a series of activities, which accelerated the expansion of the corporate scale and strength. By the end of 2015, the corporation had promoted and sold the products branded in "ZhouHeiya" mainly through the 715 self-running stores and mature online channels covering the 38 cities in 12 provinces and municipalities in China. In 2015, the corporation realized 2.432 billion Yuan of the operation revenue. The net profit during the same term reached 550 million Yuan and the compound annual rate of growth reached $45.8 \%$. It had become the corporation specified in leisure stewed products with the largest earnings.

The President of China Cuisine Association presented that the transitional adjustment for 3 years after the CPC introduced the Eight Regulations returned Chinese catering industry's growth rate back to the development speed of $11.7 \%$ [1] and the rapid growth of the catering industry had become a particular case in the time of knowledge economy. Under the background of the globalization of market economy and rapid growth of the catering industry, the constitution of 
enterprise core competitiveness gradually began to depend on high-quality talents, especially those enterprise management talents characterized in different quality, and the inadequacy of management post competence will must influence the future performance [2]. That the staff is not trained in high quality under low management at present seriously obstructs the rapid development for "ZhouHeiya". To guarantee the sustainable rapid growth and development for the corporation, staff training, especially the competence training for managerial leaders has become the priority among priorities for the corporate development strategy. Management training based on post competence is expected to combine with the individual quality and potential of management according to the practical competence requirement of the post. It is required to make an overall planning about the specific training requirement for each hierarchy, each department and each post to make scientific analysis. Then it shall establish high-quality and targeted individual training system to truly develop, enhance and excavate management' s capacity and potential, which can realize competence-post matching, mutual development of corporate and staff and the construction of enterprise core competitiveness.

\section{CASE ANALYSIS TOOLS AND DESIGN APPROACH}

Competence research and practice was the earliest formally proposed by the Professor named David McClelland in Harvard University in 1973. He believed that competence referred to a deep hierarchic individual characteristic which could distinguish those outstanding from ordinary people in a certain job. It could be any individual characteristics reliably measured or calculated to obviously distinguish outstanding performance from general one including motive, specialty, self-image, attitude or value, certain field knowledge, cognition or behavioral skills and so on [3]. Sharon and others in detail described the result-oriented management staff training system based on capacity quality model [4]. Liu Xuefang and Wang Chongming established the competence model for family enterprise successors through exploratory and confirmatory factor analysis the first time [5]. Song Peilin made research on the competence models for entrepreneurs in different stages, analyzing and concluding the competence structures for different stages in entrepreneurs' growth [6]. It is an urge to reasonably build competence model and apply it to practical enterprise training and carry out sustainable talent training mode for the sustainable development for modern enterprises.

The construction of management post competence model must be based on the analysis on the enterprise strategic development direction and operation goal. The competence model must be improved by reference to theoretical literature and benchmarking enterprises. Through the evaluation of the capacity and potential of administrators, it can confirm the training contents and training ways to design the management training system based on post competence. It can fully excavate the management post competence and administrators' capacity and potential to realize the unification of enterprise strategic development direction, operation goal and management post competence with administrators' skill training and potential development. The main contents are shown in Fig.1.

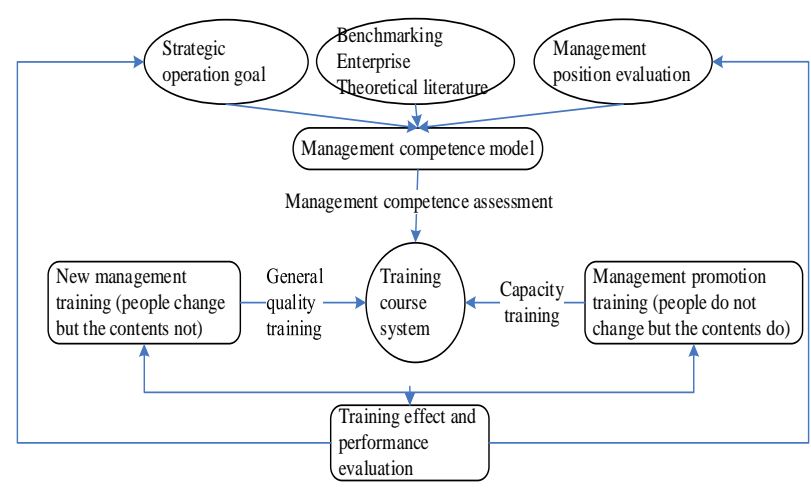

Fig. 1. Theoretical training model based on post competence

Management training based on post competence is mainly divided into two layers: one is that people change but the contents not; the other is that people do not change but the contents do. That people change without change of the contents is mainly targeted at new administrators. General quality training for management post must be carried out from ordinary staff to administrators to satisfy the management post requirement and become a qualified administrator. That people do not change but the contents do is mainly pointed at those promoted administrators. They must strengthen their management capacity from low-level administrators to highlevel administrators to satisfy the requirement of the new management post. Through competence assessment, it can confirm the training object and training content. According to the post competence requirement, it shall choose corresponding training courses and training ways from the training course system. General management quality training can be carried out by class teaching and discussion to quicken the speed of knowledge acquisition. Management capacity promotion can be trained through cooperation with colleges to confirm core course organization and arrange teaching cases, analysis method, management games and experimental learning according to the training mode for MBA talents, which can make the training more effective to strengthen administrators' quality to satisfy the promoted post competence requirement.

\section{Post Competence Evaluation And Training Scheme DESIGN}

To adhere to the enterprise value of "Customers first, team second and shareholders third", to implement the cultural value of "Entertainment makes it happier" and to realize the enterprise goal of "Century-old brand is going to the world", customers orientation and risk strain capacity and so on shall be regarded as main factors for the management competence model. NormStar declared in its Report about the Leadership Development Index for Chinese Enterprises: among 187 enterprises, the middle management leadership competence indexes used the most frequently included cooperation acceleration, effective communication, idea analysis, operation awareness, decision-making capacity and organizational 
planning [7]. Procter \& Gamble Company concluded its leadership model as 5E, Enable, Envision, Energize, Engage and Execute.

Through the analysis on the three dimensions of the enterprise strategy, it confirms the requirements for the current future competences for the post; by reference to the theoretical literature and the benchmarking enterprise competence, it analyzes the marketability and rationality of the post competence to build the competence model for middle management in ZhouHeiya. The competence model is shown in TABLE I.

\section{TABLE I. COMPETENCE MODEL FOR ZHOUHEIYA MANAGEMENT POSTS}

\begin{tabular}{|c|c|c|c|}
\hline No. & $\begin{array}{c}\text { Post } \\
\text { competence }\end{array}$ & Description & $\begin{array}{c}\text { Post value } \\
\text { of } \mathrm{Ni}\end{array}$ \\
\hline 1 & $\begin{array}{l}\text { Ability of } \\
\text { organizational } \\
\text { planning and } \\
\text { execution }\end{array}$ & $\begin{array}{l}\text { Accurately identify and effectively } \\
\text { utilize resources for reasonable } \\
\text { organization and planning. Carry out } \\
\text { work based on organizational } \\
\text { strategy. }\end{array}$ & 10 \\
\hline 2 & $\begin{array}{l}\text { Ability of } \\
\text { teamwork and } \\
\text { coordination }\end{array}$ & $\begin{array}{l}\text { Cooperate with others and } \\
\text { coordinate various relationships } \\
\text { according to the work requirement. } \\
\text { Deal with and solve various } \\
\text { problems in time. }\end{array}$ & 10 \\
\hline 3 & $\begin{array}{l}\text { Management } \\
\text { knowledge } \\
\text { and } \\
\text { individual } \\
\text { quality }\end{array}$ & $\begin{array}{l}\text { Management knowledge and } \\
\text { individual quality required in } \\
\text { management activities. }\end{array}$ & 9 \\
\hline 4 & $\begin{array}{l}\text { Crisis } \\
\text { management } \\
\text { and strain } \\
\text { capacity }\end{array}$ & $\begin{array}{l}\text { Think deeply in advance and take } \\
\text { actions to meet challenges. }\end{array}$ & 8 \\
\hline 5 & $\begin{array}{l}\text { Interpersonal } \\
\text { communicatio } \\
\text { n capacity }\end{array}$ & $\begin{array}{l}\text { Effectively communicate with others } \\
\text { to build good interpersonal } \\
\text { atmosphere. }\end{array}$ & 8 \\
\hline 6 & $\begin{array}{l}\text { Market } \\
\text { orientation } \\
\text { and } \\
\text { commercial } \\
\text { consciousness }\end{array}$ & $\begin{array}{l}\text { Catch growth opportunities for } \\
\text { products, market and regions } \\
\text { correctly and timely. }\end{array}$ & 8 \\
\hline
\end{tabular}

Among them, the industry standard for each competence factor is $\mathrm{N}$ equal to 10 . By comparison with benchmarking enterprises, it can get the post value of $\mathrm{Ni}$ required by "ZhouHeiya" management post relative to the industrial standard. By reference to the assessment table by NormStar and others, design the assessment questionnaire suitable for ZhouHeiya middle management post competence. Beside the basic information of administrators, the questionnaire content also includes two parts, respectively administrators' selfevaluation and capacity assessment, covering six post competence factors. The questionnaire is expected to get corresponding assessment results. The Radar Map is drawn as Fig.2.

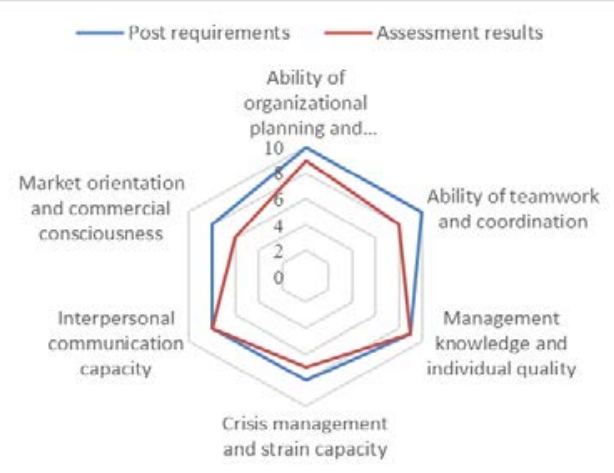

Fig. 2. Radar map for Administrator A’s post competence

In the Radar Map, the assessment result of Administrator A for six post competence factors show: only "Interpersonal communication capacity" and "Management knowledge and individual quality" satisfy the post competence requirement. It thus confirms that $A$ shall receive the training about organizational planning and executive capacity, market orientation and commercial consciousness, crisis management and strain capacity, teamwork and coordination capacity. Meanwhile, according to the features of each post competence factor and the individual condition and the practical corporate condition, choose corresponding training contents and ways in the training course system (like TABLE II).

TABLE II. TRAINING COURSE SYSTEM FOR MIDDLE MANAGEMENT

\begin{tabular}{|c|c|c|c|}
\hline $\begin{array}{c}\text { Training } \\
\text { object }\end{array}$ & $\begin{array}{l}\text { Training } \\
\text { module }\end{array}$ & Course name & $\begin{array}{c}\text { Training } \\
\text { way }\end{array}$ \\
\hline \multirow{6}{*}{$\begin{array}{c}\text { Middle } \\
\text { management }\end{array}$} & $\begin{array}{l}\text { Ability of } \\
\text { organizational } \\
\text { planning and } \\
\text { execution }\end{array}$ & $\begin{array}{l}\text { Time management } \\
\text { methods, resource } \\
\text { coordination strategy, } \\
\text { goal identification and } \\
\text { standard management. }\end{array}$ & \multirow{6}{*}{$\begin{array}{l}\text { Confirm core } \\
\text { courses and } \\
\text { arrange } \\
\text { lectures, case } \\
\text { discussion } \\
\text { and } \\
\text { management } \\
\text { games } \\
\text { cooperating } \\
\text { with colleges } \\
\text { in the way of } \\
\text { dual culture } \\
\text { and internal } \\
\text { training }\end{array}$} \\
\hline & $\begin{array}{l}\text { Ability of } \\
\text { teamwork and } \\
\text { coordination }\end{array}$ & $\begin{array}{l}\text { Conflict management, } \\
\text { teamwork training, } \\
\text { internal and external } \\
\text { relationship } \\
\text { management. }\end{array}$ & \\
\hline & $\begin{array}{l}\text { Management } \\
\text { knowledge and } \\
\text { individual } \\
\text { quality } \\
\end{array}$ & $\begin{array}{l}\text { Management } \\
\text { knowledge, training of } \\
\text { the attitude and value, } \\
\text { emotion management. }\end{array}$ & \\
\hline & $\begin{array}{c}\text { Crisis } \\
\text { management } \\
\text { and strain } \\
\text { capacity } \\
\end{array}$ & $\begin{array}{l}\text { Risk prospect, } \\
\text { management skills for } \\
\text { crisis events, pressure } \\
\text { management. }\end{array}$ & \\
\hline & $\begin{array}{c}\text { Interpersonal } \\
\text { communication } \\
\text { capacity }\end{array}$ & $\begin{array}{l}\text { Strengthening of } \\
\text { written and oral } \\
\text { communications, } \\
\text { training about } \\
\text { interpersonal feeling } \\
\text { capacity, listening and } \\
\text { feedback. }\end{array}$ & \\
\hline & $\begin{array}{l}\text { Market } \\
\text { orientation and } \\
\text { commercial } \\
\text { consciousness }\end{array}$ & $\begin{array}{l}\text { Customer } \\
\text { identification, market } \\
\text { analysis and } \\
\text { opportunity } \\
\text { identification, market } \\
\text { expectation. }\end{array}$ & \\
\hline
\end{tabular}




\section{CONCLUSiOns}

Competence-based human resource management has been extensively applied in foreign countries. It has become a consensus in the business circles for the training to become an important link in formation and sustainability of enterprise core competitiveness by combining the staff competence model with enterprise core competitiveness, future development and organizational competitiveness. However, it is still not mature of the theoretical and empirical research on post competence in China. With the development of modern training systems, it is a common topic for enterprises for how to "tailored" design training course system and ways suitable for its own culture and value and post competence requirements to strengthen the management competence and develop excellent staff. Through the practice in ZhouHeiya, I think that Chinese enterprise shall pay attention to the following three points in the training based on post competence: firstly, it shall correctly determine the post competence to confirm the basis for the training plan; secondly, the training contents and ways shall be based on the objective and correct analysis on the enterprise strategic development direction, post competence requirements and individual ability and potential. It shall insist in double orientation of strategy and ability in the confirmation of training goals, scheme design, plan implementation and effect evaluation to realize ideal training effect; lastly, the training requires full support from corporate senior management and active participation of administrators. The management training based on post competence is an important means for enterprises to strengthen its own core competitiveness. Administrators need to change the training idea from "I am required to learn" to "I want to learn". They shall take initiative to participate in the training to strengthen the ability of serving enterprise development; the enterprise shall correctly determine the post competence required by the time to fully guarantee the implementation and build and strengthen the core competitiveness.

\section{REFERENCES}

[1] Jiang Mei, "China Service" Adds Value for the Catering Industry. http://www.cnfood.cn/n/2016/0419/84106.html, 2016-04-19.

[2] De Qin, Investigation Report of the Enterprise Leadership Development in China [R]. 2013.

[3] McClelland D C. Testing for Competence Rather than for Intelligence [J]. American Psychologist, 1973(28):1-14

[4] Sharon S N, Elwood F H. Leadership and Managerial Competency Models: A Simplified Process and Resulting Model [J]. Advances in Developing Human Resources, 2006(2):144-165.

[5] Liu Xuefang, Wang Chongming, Tang Ningyu, Zhu Jian and Ni Ning, Competence Model for Family Enterprise Successors - A Empirical Research [J]. Management World, 2006(5):96-06. (In Chinese)

[6] Song Peilin, Analysis on the Entrepreneur Competence Structure in Different Enterprise Development Stages [J]. Management, 2010(2):5161. (In Chinese)

[7] NormStar, Report about the Leadership Development Index for Chinese Enterprises [R]. 2013. 